\title{
An Evaluation of the Impact of Nigeria's Trade and Investment Policy Reforms ${ }^{\vee}$
}

\author{
by \\ E. Olawale OGUNKOLA \\ Abiodun S. BANKOLE \\ Adeolu O. ADEWUYI \\ Trade Policy Research and Training Programme (TPRTP) \\ Department of Economics \\ University of Ibadan
}

March 2006

\footnotetext{
"An abridged version of the Final Report of a study supported by the African Economic Research Consortium (AERC), Nairobi, Kenya. The authors are research Fellows in the Trade Policy Research and Training Programme (TPRTP) in the Department of Economics, University of Ibadan, Nigeria.
} 


\section{Introduction}

Nigeria, like many other countries, is currently engaged in an array of economic reforms negotiations aimed at promoting development and reducing poverty. At the regional level, investment and trade reforms are significant components of the Economic Community of West African States (ECOWAS) negotiations. As a founding member of ECOWAS in 1975, the country has consistently pursued the quest for improved market access conditions simultaneously with policies that will strengthen the weak supply response capacity. While trade and investment components of the negotiations are not new to the regional arrangement, the current momentum is understandable in the context of the relationship between the European Union and the African-Caribbean-Pacific (ACP) countries that is currently being redefined. Indeed, the on going negotiations of the Economic Partnership Agreement (EPA) which is the economic component of the Cotonou Partnership Agreement (CPA) focus on trade and investment reforms. The negotiations of an EPA between West Africa and the European Union (EU) which is scheduled to be on till December 2007 constitute the second major negotiations which Nigeria is expected to be actively engaged. Beyond the negotiations of intra- and extra-regional agreements, the country, a founding member of the World Trade Organisation (WTO) is currently participating in the multilateral negotiations of trade and investment under the Doha development agenda. This constitutes the third major negotiations that the country is currently engaged in.

The current frenzy about negotiations should benefit from the experience with previous reforms that characterised the mid 1980s of which trade and investment are the major components. Starting with the structural adjustment programme (SAP) in the mid 1980s, and moving to the current home-grown National Economic Empowerment Development Strategies (NEEDS), different reforms in trade and investment components points to the liberalisation stance of the government. The reforms encompass changes in policy directions as well as policy instruments. Investment policy, for instance, witnessed a radical reform as the indigenisation policy of the government was abandoned in favour of a liberalised (foreign and domestic) investment regime. In most cases institutional reforms constituted a major component of the package. Again in the area of investment policy, the Nigerian Investment Promotion Commission (NIPC) was not only reinvigorated but also strengthened to discharge its redefined statutory functions.

Indeed, SAP was a watershed in the history of trade and investment policy reforms in the country. The Programme was able to achieve substantial reduction in average tariffs and also saw to the minimal application of quantitative import restrictions. As a comprehensive approach to restructure the Nigerian economy, the Programme contains policies that are complementary to trade and investment especially foreign exchange reform.

This study examines and evaluates the impact of trade and investment policy reforms on some macroeconomic performance variables. It simulates the impact of entrenched policy scenarios on growth variables. The lessons from the simulation experiments provide useful inputs into on-going negotiations. The rest of this paper is structured as follows; Section II reviews the structure and performance of the Nigerian economy. Section III presents theoretical and analytical framework of the study, while Section IV contains 
methodology. Section V is on the empirical analysis and Simulation. Section VI provides the summary, policy implications and conclusion.

\section{Structure and Performance of the Nigerian Economy}

\subsection{Growth Performance and Structure of Output in Nigeria}

Aggregate and sectoral output growth performance of the Nigerian economy over the study period is presented in table 2.1. It can be seen from the table that aggregate output which declined by 3.0 per cent in the $1980-85$ period rose by 5.0 per cent in the following $1985-90$ period. It can also be observed from the table that growth of output of the main sectors of the economy (agriculture, industry and services) during the two periods followed the same pattern. The largest decrease in sectoral output during the 1980-85 period was witnessed in the industrial sector, while the lowest was recorded in the services sector. Further, the highest increase in output during the 1985-90 period was recorded by the services sector, while the lowest was experienced in the industrial sector. The poor output growth performance of the economy during 198085 period was not unconnected with various macroeconomic crises which adversely affected productivity in all sectors of the economy. It should be stated that the after effects of the collapse of the world price of crude oil in the late 1970s was fiscal and balance of payments deficits which led to rising and accumulated domestic and external debts with negative consequences on investment and output growth.

Against the backdrop of the persistence of the macroeconomic crises even after the introduction of stabilization measures in 1982, the Structural Adjustment Programme (SAP) was adopted in Nigeria in 1986. Among the policies and programmes packaged in SAP were trade and financial liberalisation, export and investment promotion and privatisation and commercialization. All these policy reforms might have promoted sectoral and aggregate output growth performance recorded during 1985-1990 period. The subsequent periods 1990-1995 and 1995-2000 witnessed declining rate of growth of aggregate output and differences in sectoral output growth. Thus, the rate of growth of aggregate output which was 5.0 percent in 1985-1990 period fell to 3.4 percent in 1990-1995 period and to 2.9 percent in 1995-2000 period. It should be noted that the rate of growth of output of the services sector which was the highest in the previous periods fell to 2.5 percent $n$ the $1995-2000$ period. The unimpressive growth performance recorded by the industrial sector during 1990-1995 gradually improved in the subsequent 1995-2000 period, while agricultural sector recorded the highest increase in output during the period. However, SAP was scrapped towards the end of 1993.

The period 2000-2004 witnessed improved aggregate and sectoral growth performance because, the growth performance of the economy improved from 2.9 percent in 1995-2000 period to 6.0 percent in 20002004 period. Similarly, the rate of sectoral output growth improved significantly particularly in the industrial and services sectors. During this period, sectoral rates of growth ranged between 5.0 and 7.0 percent. This impressive output growth performance recorded by the Nigerian economy can be attributed largely to favourable development in the foreign crude oil market in form of substantial improvement in terms of trade and relatively high volume of oil export. The reform programmes introduced by the current democratic government in Nigeria might have also contributed to the improvement recorded in the non-oil sector of the 
economy. Thus, with the current average output growth rate of about 6.0, Nigeria can reach a sustainable rate of growth of 7.0 percent required for poverty alleviation as recommended in most poverty reduction strategies (PRS) such as the Millennium Development Goals (MDGs) and the New Partnership for African Development.

An assessment of the level of industrialization and economic development achieved in a country can be conducted by examining the structure of output in that country. Table 2.1 indicates that, as at 1980, industrial sector contributed almost half of the total output in Nigeria. This is followed by the services sector which accounted for over 30.0 percent of total output. By 1990, the structure of output had changed just slightly with the industrial sector continuing to play the leading role while the agricultural sector had displaced the services sector as the second growth driver. By 1995, there was a further shift in the structure of output in Nigeria, as the agricultural sector had also displaced the industrial sector in terms of its share of total output of the economy which was about 43.0 per cent. Next to the agricultural sector was the services sector which accounted for 31.0 percent of total output. In the early 2000s, the industrial sector resumed its leading role by accounting for 45.0, 49.0 and 39.0 per cent of total output in 2001, 2003 and 2004 respectively. This is followed by the agricultural sector which contributed between 26.0 and 31.0 per cent of the total output during this period. Thus, Nigeria's development experience has not followed the path of industrialisation, particularly because, instead of declining to a relatively low level, the contribution of the agricultural sector over time has increased and remained relatively high. This therefore informs the need for renewed economic reform efforts and policy programmes to transform the Nigerian economy from agrarian to an industrialised entity. The role of investment and trade policy reforms is germane towards this course.

Table 2.1: Nigeria: Average Annual Growth Rate of the economy (Aggregate and Sectoral) and Structure of output

\begin{tabular}{|c|l|l|l|l|l|}
\hline Aggregate and sectoral growth & $\mathbf{1 9 8 0 - 8 5}$ & $\mathbf{1 9 8 5 - 9 0}$ & $\mathbf{1 9 9 0 - 9 5}$ & $\mathbf{1 9 9 5 - 2 0 0 0}$ & $\mathbf{2 0 0 0 - 0 4}$ \\
\hline (A) Aggregate output growth & -3.0 & 5.0 & 3.4 & 2.9 & 5.96 \\
\hline (B) Sectoral output growth & & & & & \\
\hline$\bullet \quad$ Agriculture & -1.5 & 6.4 & 2.7 & 4.5 & 5.27 \\
\hline$\bullet \quad$ Industry & -6.1 & 2.1 & -0.5 & 1.8 & 6.78 \\
\hline$\bullet \quad$ Services & -0.3 & 7.6 & 6.8 & 2.5 & 6.74 \\
\hline Sectoral share of GDP & $\mathbf{1 9 8 0}$ & $\mathbf{1 9 9 0}$ & $\mathbf{1 9 9 5}$ & $\mathbf{2 0 0 1}$ & $\mathbf{2 0 0 4}$ \\
\hline$\bullet \quad$ Agriculture & 27.0 & 33.0 & 43.0 & 30.0 & 31.0 \\
\hline$\bullet \quad$ Industry & 40.0 & 41.0 & 26.0 & 45.0 & 39.0 \\
\hline$\bullet \quad$ Services & 33.0 & 26.0 & 31.0 & 25.0 & 30.0 \\
\hline$\bullet \quad$ Total & $\mathbf{1 0 0 . 0}$ & $\mathbf{1 0 0 . 0}$ & $\mathbf{1 0 0 . 0}$ & $\mathbf{1 0 0 . 0}$ & $\mathbf{1 0 0 . 0}$ \\
\hline
\end{tabular}

Source: The World Bank, African Development Indicators, Washington, DC.

Note * Figure obtained from the Central Bank of Nigeria, Annual Report and Statement of Accounts (2004), Abuja

\subsection{Rate and Structure of Investment and Savings}

Average annual rates of investment and savings are presented in Table 2.2. Domestic aggregate investment rate has increased over time. It rose from about 14.0 per cent in the period 1980-1985 to 15.0 per cent in 1985-1990 period and further to about 20.0 and 21.0 per cent in 1990-1995 and 1995-2000 periods and reached over 23.0 per cent in 2002. Continuous rise in the average rate of aggregate domestic investment over time is explained by the fact that private domestic investment rate rose faster than public domestic investment rate until 2001 when the latter began to rise again. Private investment rate rose from 6.1 
per cent in 1985-1990 period to 11.8 and 12.1 per cent in 1990-1995 and 1995-2000 respectively. Public investment rate however, fell from 9.1 percent in 1985-1990 period to 8.2 per cent in 1990-2000 and started picking-up again in 2001 and 2002. This therefore suggests that as public investment rate decreased as a result of adjustment reform programmes (privatisation and commercialization implemented since 1986), private investment rate increased. Table 2.3, however, indicates that the high and continuous rise in lending rate has resulted in marginal rise in the rate of investments.

With respect to domestic savings rate, table 2.3 also indicates that it has assumed an upward trend over time until 2002 when it fell to less than 20.0 per cent. Thus, domestic savings rate which was about 14.0 percent in the 1980-1985 period increased to about 18.0 and 24.0 percent in the periods $1985-1990$ and 1990-1995 respectively and reached over 25.0 percent in 1995-2000. The rate of domestic savings was particularly low in the 1980-1985 period due to the trends of its fundamental determinants, namely output and savings-deposit rate. Total output/income of the economy declined (on the average) during this period while the savings - deposit rate was relatively low (Table 2.3). The improved output growth performance (and hence increased national income) coupled with increased savings - deposit rate witnessed during late 1980s and 1990s might have accounted for the rise in domestic savings rate in the subsequent periods.

The extent to which the prevailing macroeconomic environment promotes investment (both domestic and foreign) in Nigeria can be gauged by examining the gap between domestic savings and investment as well as the rate of foreign direct investment in Nigeria. Table 2.2 shows that the gap between domestic savings and investment has continued to widen over time. This gap which was very insignificant in the period 1980-1985, became significant in the subsequent periods, and by the period 1995-2000, it was over 5.0 per cent. It should be noted that, by 2002 domestic savings was no longer sufficient to finance domestic investment. The foregoing suggests that macroeconomic environment or condition which prevailed during the late 1990s and early 2000s was not conducive for investment. Thus, it can be seen from Table 2.3 that as a result of the implementation of adjustment programme (SAP) exchange rate has persistently depreciated most of the time while lending rate has been high. All these have resulted into high cost of investment and production, which contributed to high rate of inflation during these periods. The relatively low rate of foreign direct investment (FDI) in Nigeria is also a reflection of inauspicious macroeconomic environment. The rate of FDI in Nigeria was very low as it was about 1.0 percent in 1980 - 85 before rising to over 4.0 percent in 1990-1995. It has however declined to 2.6 per cent in 2001 and later rose to 4.1 per cent in 2002. There is therefore the need to ensure favourable macroeconomic environment to promote savings and investment (both domestic and foreign) and hence, stimulate economic growth in Nigeria. This again necessitates investment policy reform in Nigeria.

Table 2.2: Nigeria: Average Annual Rate of Investment and Savings (Gross Domestic Investment and Savings as a ratio of GDP)

\begin{tabular}{|l|l|l|l|l|l|l|}
\hline Structure & $\mathbf{1 9 8 0 - 8 5}$ & $\mathbf{1 9 8 5 - 9 0}$ & $\mathbf{1 9 9 0 - 9 5}$ & $\mathbf{1 9 9 5 - 2 0 0 0}$ & $\mathbf{2 0 0 1}$ & $\mathbf{2 0 0 2}$ \\
\hline (A) Domestic aggreg. investment & 13.7 & 15.1 & 19.8 & 20.4 & 20.0 & 23.3 \\
\hline (B) Domestic Sectoral investment & $\%$ & $\%$ & $\%$ & $\%$ & $\%$ & $\%$ \\
\hline$\bullet \quad$ Public & $\mathrm{Na}$ & 9.1 & 8.2 & 8.3 & 14.1 & 11.7 \\
\hline$\bullet \quad$ Private & $\mathrm{Na}$ & 6.1 & 11.8 & 12.1 & 5.9 & 11.6 \\
\hline
\end{tabular}




\begin{tabular}{|l|l|l|l|l|l|l|}
\hline (C) Domestic Savings & 13.9 & 17.7 & 23.6 & 25.4 & 24.5 & 17.4 \\
\hline (D) Savings- Investment Gap & 0.2 & 2.6 & 3.8 & 5.0 & 4.5 & -5.9 \\
\hline (E) Gross Foreign Direct Investment & 1.06 & 2.82 & 4.31 & 3.75 & 2.6 & 4.1 \\
\hline
\end{tabular}

Source: The World Bank, African Development indicators, and World Development Indicators, Washington, DC.

Note: *Figure obtained from the Central Bank of Nigeria, Annual Report and statement of Account (2004), Abuja.

Table 2.3: Macroeconomic Determinants of Savings and Investment in Nigeria, 1980- 2004

\begin{tabular}{|l|l|l|l|l|}
\hline Year/indicator & Savings-deposit rate & Lending rate & Inflation rate & Exch. rate (N to US \$) \\
\hline 1980 & 6.0 & 9.5 & 9.9 & 0.55 \\
\hline 1982 & 7.5 & 11.8 & 7.7 & 0.67 \\
\hline 1984 & 9.5 & 13.0 & 39.6 & 0.76 \\
\hline 1986 & 9.5 & 12.0 & 5.4 & 2.02 \\
\hline 1988 & 14.5 & 17.6 & 38.3 & 4.53 \\
\hline 1990 & 18.8 & 20.6 & 7.5 & 8.04 \\
\hline 1992 & 16.1 & 31.2 & 44.5 & 17.30 \\
\hline 1995 & 12.6 & 20.8 & 72.8 & 81.30 \\
\hline 1996 & 11.7 & 20.8 & 29.3 & 81.50 \\
\hline 1997 & 4.8 & 20.9 & 8.5 & 82.0 \\
\hline 1998 & 5.5 & 21.8 & 10.0 & 84.4 \\
\hline 1999 & 5.3 & 33.1 & 6.6 & 92.3 \\
\hline 2000 & 5.3 & 26.4 & 6.9 & 101.7 \\
\hline 2001 & 5.4 & 31.2 & 18.9 & 111.9 \\
\hline 2002 & 4.3 & 25.7 & 12.9 & 121.0 \\
\hline 2003 & 4.2 & 21.6 & 14.0 & 129.3 \\
\hline 2004 & 4.4 & 20.4 & 15.0 & 133.5 \\
\hline
\end{tabular}

Source: Central Bank of Nigeria, Statistical Bulletin and Annual Report and Statement of Accounts, various years. Note * indicates Average Official exchange rate

\section{3: Performance and Structure of Nigeria's Trade}

Performance and structure of external trade as well as trade positions are presented in Tables 2.4, 2.5 and 2.6. Table 2.4 that export performance has varied over time. Thus, real export of goods and services which declined by about 8.0 percent in the 1980-85 period rose by about 13.0 percent in the 1985-90 period. The poor export performance in the 1980-85 period can be attributed to unfavourable and fluctuating terms of trade as well as internal macroeconomic crises which adversely affected domestic supply capacity and international competitiveness of exports. The introduction of the adjustment reform (SAP) might have led to improved export performance recorded in the 1985-90 period. However, by 1990-95 period, the improved export performance witnessed in the previous period was not sustained as real export of goods and services declined by over 5.0 percent. Nonetheless, it has risen by about 29.0 and 6.5 per cent in the subsequent periods.

Real imports which fell by about 16.5 and 1.6 percent in the periods 1980-85 and 1985-90 respectively rose steadily in the subsequent periods by between 3.0 and 7.5 per cent. The macroeconomic crises in the early 1980s which affected real export performance also affected imports. However, the improved income growth experienced in the subsequent periods stimulated rapid growth of imports. Developmental programmes and promotion of private investment embarked upon in recent times also contributed to rapid growth of real imports particularly in the early 2000s.

An examination of the contribution of external trade to gross domestic output (GDP) reveals that the share of export in GDP has increased continuously over time, while that of import has dwindled. The share of export in GDP rose from 18.4 percent in the 1980-85 period to 40.7 percent in the 1995-2000 period, and dropped slightly to 38.4 percent in 2000-2004 period. This impressive export performance is due to the 
favourable development in the oil export market over time, as the share of oil export in GDP rose from 17.8 percent in 1980-85 period to over 35.0 percent in 1995-2004 period. The contribution of non-oil export to GDP has been abysmally low over time. Consequently, Nigeria's export sector has remained undiversified despite all efforts including the reform programmes and incentives. This therefore calls for a re-examination and fine tuning of reform policies and programmes directed at stimulating non-oil exports in Nigeria. With respect to the contribution of imports to GDP, it has varied over time. The share of imports in GDP which was about 16.9 percent in 1980-85 period, fell to about 13.6 percent in 1985-1990 period. Subsequently, it rose from about 25.4 and 27.7 percent in 1990-1995 and 1995-2000 periods respectively, before it fell to 25.5 percent in 2000-2004 period. The contribution of imports to GDP had been driven by non-oil imports which accounted for a significant proportion of the share of imports in GDP. Overall, the share of total trade (export and import) in GDP has followed the trend of export share in GDP, which has consistently risen over time from over 35.0 percent in 1980-90 to over 62.0 percent in 1990-2004. This implies that the degree of openness of the Nigerian economy has increased substantially overtime. However, the associated benefits of increased openness of an economy in terms of substantial improvements in income growth and poverty level are yet to be fully reaped in Nigeria. The present condition can be improved when adjustment reforms lead to diversification from oil to non-oil activities such that manufacturing and other industrial sub-sectors become the growth drivers. This is based on the fact that very few people in Nigeria participate in oil sector activities which accounted for overwhelming proportion of total export and a reasonable share of GDP. Given the performance of exports vis-à-vis imports, it is not unexpected that current account positions will be favourable over time. The merchandise account was favourable throughout the periods under review, while the services and income accounts were unfavourable most times. However, the overall current account position was favourable most years particularly in the selected years except 1995 when it was unfavourable.

Table 2.4: Trade Performance in Nigeria

\begin{tabular}{|c|c|c|c|c|c|}
\hline Indicator & 1980-85 & 1985-90 & 1990-95 & $1995-00$ & $2000-04 *$ \\
\hline \multicolumn{6}{|l|}{ (A) GROWTH PERFORMANCE } \\
\hline Growth of real export of goods and services & -7.68 & 12.86 & -5.33 & 28.88 & 6.5 \\
\hline Growth of real import of goods and services & -16.48 & -1.61 & 3.75 & 7.35 & 4.5 \\
\hline \multicolumn{6}{|l|}{ (B) SHARE OF TRADE IN GDP } \\
\hline Share of total export in GDP & 18.40 & 24.62 & 36.90 & 40.74 & 38.40 \\
\hline Share of oil export in GDP & 17.77 & 23.29 & 35.91 & 39.84 & 37.83 \\
\hline Share of non-oil export in GDP & 0.63 & 1.33 & 1.0 & 0.9 & 0.58 \\
\hline Share of total import in GDP & 16.94 & 13.59 & 25.35 & 27.68 & 25.53 \\
\hline Share of oil import in GDP & 0.33 & 1.90 & 4.49 & 6.15 & 4.42 \\
\hline Share of non-oil import in GDP & 16.61 & 11.69 & 20.86 & 21.53 & 21.12 \\
\hline Share of total Trade in GDP & 35.34 & 38.21 & 62.25 & 68.42 & 63.93 \\
\hline \multicolumn{6}{|l|}{ (C) TRADE POSITION** } \\
\hline Current Account balance & $13,057.9$ & $10,738.9$ & 79810.1 & $-186,085$ & $1,054,635$ \\
\hline (a) Merchandise Acct. & $13,975.8$ & $11,421.4$ & $76,188.0$ & 247,178 & $1,567,454$ \\
\hline (b) Export Acct. & $14,186.0$ & $11,720.8$ & $109,880.0$ & 825,670 & $2,924,135$ \\
\hline (c) Import Acct. & -210.2 & -229.4 & $-33,698.1$ & -578492 & $-1,356,681$ \\
\hline (d) Services and income & -3462.2 & -2617.7 & $-28,998.3$ & -484811 & -713654 \\
\hline
\end{tabular}

Source: Underlying data obtained from (i) Central Bank of Nigeria (CBN), Statistical Bulletin and Annual Report and Statement of Accounts, various years; and (ii) Federal Office of Statistics (FOS), National accounts statistics. Note: * indicate data are obtained from the World Bank, World Development Indicators **indicates data are for 1980, 1985, 1990, 1995 and 2003.

Table 2.5 shows the dominance of oil exports over the period under review, as it accounted for between 94.0 and 98.0 percent of total exports. Except in 2000 - 04 period, agriculture contributed the 
substantial portion of non-oil export as its share has ranged between 64.0 and 72.0 percent during these periods. This implies that the share of manufacturing sector in non-oil export has not been significant except in 2000 - 04 when it was about 54.0 percent. Although the share of agriculture in non-oil export has been substantial, its contribution to total export has been very low and declining, while that of manufacturing has been lower and less than 1.0 percent over time. It can be deduced from the table that, since mining accounted for over 90.0 percent of total export therefore all efforts directed at diversifying export from oil to non-oil products are yet to materialize. This situation has made Nigerian economy to be vulnerable to external shocks and has limited the scope and effectiveness of macro-economic policies in promoting external trade.

Table 2.5: Structure of Nigeria's Export

\begin{tabular}{|l|l|l|l|l|l|}
\hline Table 2.5: Structure of Nigeria's Export & $1980-85$ & $1985-90$ & $1990-95$ & $1995-00$ & $2000-04$ \\
\hline Share of oil in total export & 96.59 & 94.26 & 97.33 & 97.67 & 97.45 \\
\hline Share of non-oil in total export & 3.41 & 5.74 & 2.67 & 2.33 & 2.55 \\
\hline Share of Agriculture. in non-oil export & 70.89 & 64.98 & 72.03 & 67.04 & $33.0 *$ \\
\hline Share of Manufacturing in non-oil export & 12.38 & 6.48 & 6.38 & 19.23 & $53.9 *$ \\
\hline Other non-oil export & 16.73 & 28.54 & 21.69 & 13.73 & $11.2^{*}$ \\
\hline Composition of export & $\mathbf{1 0 0 . 0}$ & $\mathbf{1 0 0 . 0}$ & $\mathbf{1 0 0 . 0}$ & $\mathbf{1 0 0 . 0}$ & $\mathbf{1 0 0 . 0}$ \\
\hline Agriculture & 2.2 & 3.75 & 1.93 & 1.68 & $1.46^{*}$ \\
\hline Mining & 96.8 & 94.27 & 97.32 & 97.40 & 97.34 \\
\hline Textile & 0.0 & 0.05 & 0.15 & 0.13 & 0.14 \\
\hline Manufacturing & 0.47 & 0.4 & 0.5 & 0.8 & 0.6 \\
\hline Others & 0.58 & 1.5 & 0.1 & 0.18 & 0.23 \\
\hline Total & $\mathbf{1 0 0 . 0}$ & $\mathbf{1 0 0 . 0}$ & $\mathbf{1 0 0 . 0}$ & $\mathbf{1 0 0 . 0}$ & $\mathbf{1 0 0 . 0}$ \\
\hline
\end{tabular}

Source: Underlying data obtained from the Central Bank of Nigeria (CBN), Statistical Bulletin and Annual Report and Statement of Accounts, various years. Note: * indicates data are for 2004.

With respect to import, Table 2.6 reveals that non-oil activity has dominated, as it accounted for between 77.0 and 98.0 percent. This dominance has however reduced overtime, from about 98.0 percent in 1980 - 85 to about 77.0 percent in 1995 - 2000 period, even though this share has risen again to about 82.0 percent in 2000 - 04 period. At a more disaggregated level, manufacturing accounted for between 77.0 and 87.5 percent, while the share of agriculture ranged between 9.0 and 18.5 percent. Manufacturing share of total import rose from over 77.0 percent in 1980 - 85 to over 87.0 percent in 1990 - 95 and stood at about 80.0 percent in the subsequent periods. However, the share of agriculture in total import declined from about 18.4 percent in 1980 - 85 to about 9.2 percent in 1990 - 95 and hovered around 14.0 percent in the subsequent periods. The share of mineral fuel has remained very low over the periods. Thus, there is a heavy reliance of the manufacturing sector on imports. This is confirmed by the the uses into which imported commodities are put. Capital goods and raw materials which are production inputs constitute 65 70 percent of total imports between 1980 and 1995 and about 80.0 percent beginning from late 1990s. This implies that Nigeria depends more on import for production inputs than for consumption goods, thus, creating a desirable market for locally made goods. However, local substitutes need to be developed for imported inputs so as to reduce the level of dependence and conserve foreign exchange.

Table 2.6: Structure of Import in Nigeria

\begin{tabular}{|l|l|l|l|l|l|}
\hline Structure (\%) & $1980-85$ & $1985-90$ & $1990-95$ & $1995-00$ & $2000-04$ \\
\hline Share of oil in total import & 2.02 & 13.32 & 17.87 & 22.56 & 17.66 \\
\hline Share of non-oil in total import & 97.98 & 86.68 & 82.13 & 77.44 & 82.34 \\
\hline Total & $\mathbf{1 0 0 . 0}$ & $\mathbf{1 0 0 . 0}$ & $\mathbf{1 0 0 . 0}$ & $\mathbf{1 0 0 . 0}$ & $\mathbf{1 0 0 . 0}$ \\
\hline Share of Agriculture in total import & 18.39 & 11.79 & 9.22 & 14.0 & 13.93 \\
\hline
\end{tabular}




\begin{tabular}{|l|l|l|l|l|l|}
\hline Share of Manufacturing in total import & 77.18 & 83.69 & 87.13 & 79.88 & 79.58 \\
\hline Share of Mineral fuel in import & 1.13 & 0.69 & 0.64 & 1.35 & 1.43 \\
\hline Other import & 3.24 & 3.80 & 3.0 & 4.77 & 5.06 \\
\hline Total & $\mathbf{1 0 0 . 0}$ & $\mathbf{1 0 0 . 0}$ & $\mathbf{1 0 0 . 0}$ & $\mathbf{1 0 0 . 0}$ & $\mathbf{1 0 0 . 0}$ \\
\hline Composition of import & $\mathbf{( \% )}$ & $\mathbf{( \% )}$ & $\mathbf{( \% )}$ & $\mathbf{( \% )}$ & $(\boldsymbol{\%})$ \\
\hline Consumer goods & 32.87 & 39.27 & 30.48 & 20.85 & 21.05 \\
\hline Capital goods & 27.87 & 33.03 & 37.75 & 41.08 & 39.17 \\
\hline Raw materials & 39.26 & 27.70 & 31.77 & 38.07 & 39.78 \\
\hline Total & $\mathbf{1 0 0 . 0}$ & $\mathbf{1 0 0 . 0}$ & $\mathbf{1 0 0 . 0}$ & $\mathbf{1 0 0 . 0}$ & $\mathbf{1 0 0 . 0}$ \\
\hline
\end{tabular}

Source: Underlying data obtained from the Central Bank of Nigeria (CBN), Statistical

Bulletin and Annual Report and Statement of Accounts, various years.

\section{Theoretical and Analytical Framework}

An evaluation of trade and investment reforms as required in this study can be viewed from at least two perspectives which are more of two sides of the same coin. First, the evaluation may be conducted with a view to ascertain whether or not the objectives that the reforms were set out to achieve were realized and to explain the observed performance relative to these goals. A thorough analysis is then required if observed performance relative to the set goals and objectives are at variance. It is at this stage that the level of ambition, the design and the rate and sequencing of implementation are examined. Are the objectives too ambitious? Does the design of the reforms take into cognizance the structural constraints of the economy? Is the implementation consistent, adequate and appropriately sequenced? These and other pertinent analyses are useful in ex-post analysis of trade and investment reforms.

Second and related to the first is that an evaluation of the impact of trade and investment reforms can be guided by theories. In this case, the channels through which trade and investment reforms impact on the structure and performance of the economy can be traced. However, in order to have better understanding and for us to put future trade and investment reforms in the proper perspective, there is the need to explore channels through which reforms are expected to impact on the performance of an economy. Specifically, the first level of analysis is ex-post and the second level of analysis though basically is ex-ante draws inferences from the ex-post analysis. The impact of trade reform on growth is neither direct nor automatic. Trade reform works through some intermediate variables to affect growth. Some studies have focused on these intermediate variables such as employment, investment, productivity, industrial development etc. Nevertheless, these variables are the channels through which trade reform impacts on growth or performance of an economy. Some studies have examined the impact of trade reform on poverty thus, incorporating distribution issues into the possible trade-induced growth.

While few of these studies focus on trade-investment-growth nexus, an emerging consensus is that the impact of trade reform on economic performance works through investment. Thus, factors inhibiting the response of investment to trade liberalization are capable of limiting the potential benefit from trade reform. This is true of other required complementary reforms such as in the case of foreign exchange and also in the case of addressing a host of other macroeconomic variables and factors that inhibit effective supply response. In other words, optimal effectiveness of trade reform depends on the investment policy environment.

Wacziarg (2001) identified and analyzed some channels through which trade reform impact on growth to include government policy (macroeconomic policy and size of government), allocation and 
distribution (price distortion and factor accumulation) and technological transmission (technology transmission and foreign direct investment). Trade policy reforms through binding commitments provide required external anchor for government policies. The consequences of not been virtuous in other policy handles are usually devastating such as in the case of capital flight and migration of skilled manpower. It is generally agreed that effective trade policy reform potentially tied the hands of government especially when the commitments are binding at regional and/or multilateral levels. The effects of trade policy reforms on government activity and its size is subject to empirical verification as large government size may insulate consumers from various shocks. However, the need to ensure that the economic activities are competitive may limit the size of government and in this sense large size of government is inconsistent with liberal trade reform. An open economy is expected to be characterised by a lower degree of price distortion. The argument is simply that free trade facilitates international price convergence through the law of one price. The link between price distortions and factor accumulation and growth has been shown to be negative. Price stability and convergence facilitates investment (Easterly 1989 and 1993).

Factor accumulation (investment) is a channel through which trade liberalization impact on the performance of the economy. Levine and Renelt (1992) Baldwin and Seghezza (1996) and Wacziarg (2001) among others have shown that an increase in wage-rental ratio, as a result of an adoption of liberal trade regime will lead to an increase in the rate of investment. The impact of trade liberalization on investment has also been explained through the big push hypothesis. That is, liberal trade regime removes constraints of market size and thus generates impetus for new investment. Put differently, 'the entry of new firms on export markets, after an episode of liberalization, may well entail large fixed investment’ Wacziarg (2001). Liberal trade regime may as well remove or relax structural constraint to capital goods imports.

Endogenous growth model emphasizes the role of technical capabilities in facilitating technological transmission. Thus the model distinguishes between skilled and unskilled labour as the quality of available labour impacts on the process of technology transmission. Trade reform enhances technology transmission by making embodied technology available through traded goods and services. The higher the frequency and volume of international trade transactions, the higher the possibility of imitations of foreign technologies. Apart from transmission of technologies through efforts geared at meeting specific requirements of different markets, embodied technological transmission has greatest potential in capital goods imports.

Foreign direct investment (FDI) is another channel through which foreign technology permeates domestic economy. Irrespective of the type of FDI, various stakeholders tend to acquire one form of technological capabilities or the other. It has been argued that capital goods imports tend to promote technological capabilities more than FDI. Once capital goods are imported indigenous technologists are responsible for their operations, maintenance and repair. In some cases, they modify and extend the imported machinery and equipment. In the case of FDI, even if indigenous hands carried out all these activities, they are subject to control by the parent companies (Ogunkola, 2002). In any case, the effect of trade reform on FDI is not a priori clear. Changes in the level of FDI depend on the type and structure of FDI in the pre-reform period and the content and level of implementation of reform and other 
complementary policy reform. In a situation where trade reform increases the level of FDI, its effectiveness interfering technology has the greatest potential of impacting positively on growth.

Different authors have emphasized different channels, with a few of them concentrating on tradeinvestment-growth linkages (Levine and Renelt, (1992), Oyejide and Ogunkola (forthcoming). The starting point is that trade reform and economic growth is related and that the relationship is mediated through investment (Oyejide and Ogunkola (forthcoming). Explanation as to how trade and growth are related through investment is usually cast in the framework of the new growth model. By classifying goods and services according to their factor intensities: physical capital; human capital and labour and assuming traded goods sectors are more physical capital-intensive than non-traded sector, trade reform is expected to drive up the demand for physical capital in the first instance and consequently raise the return on capital and thus boost investment. Two levels of linkages have been identified: First, the link between liberal trade reform and traded sector. This postulates that trade liberalization boosts traded sector. The extent to which trade liberalization induces expansion of traded sector depends on some other factors. At the second level of the linkage, traded input goods are assumed to be an input into investment. Put differently, liberal trade regime works through reduction in inputs costs, to lowering marginal cost of investment goods and services and thereby reduces the cost of capital and, all things being equal, increases the level of investment.

In sum, new growth theory emphasizes the role of human capital through research and development activities. A major part of this theory focuses on the relationship between trade and growth. The implication of this relationship for trade policy reform can be traced through changes in relative prices. However, the effect of trade reform on growth is not definite. Trade reform may increase or decrease growth rate depending on the pattern of imports and exports (Baldwin 2003). Thus, empirical analysis is required to determine the ultimate effect of liberal trade regime.

Empirical evaluation of different channels through which trade and investment reforms impact on economic performance must, among other things, address the issue of measurement such as finding appropriate proxies for some variables (macroeconomic policy, and even trade policy index). The empirical analysis is complicated in the sense that trade reform even without investment reform impacts on the performance of an economy through investment. When trade and investment reforms are combined, empirical problem of identification cannot be ruled out. It may be difficult separating the changes in the growth of an economy, as a result of trade and investment reforms into different components. Perhaps a plausible method is to explicitly model the effect of trade reform on growth and/or performance index. Call this model restricted model. An unrestricted model is then formulated to incorporate an investment dummy variable into the restricted model to capture change in investment regime. A test is then performed to determine whether or not the dummy is statistically significant. If the dummy is statistically significant, then a model to capture the effect of investment reform on the economy in a simultaneous system with the trade reform will be attempted.

The trade literature has concerned itself with the nature and extent of short-term adjustment costs and long term benefits of trade and investment liberalizations. In the case of trade liberalization, which is construed to imply export promotion and import policy reform, its full benefits have basically been 
envisaged to be derived on a long term basis granting the absence of liberalization policy reversal which works to truncate the process generating expected benefits. Received wisdom about the costs of import liberalization revolves around three issues namely, generation of a more binding fiscal constraint, deindustrialization and creation of unemployment through unfair import competition to domestic producers, and bringing about balance of payment deficits. On the other hand, export policy reform is expected to only provide benefits in terms of lessening a country's foreign exchange constraints and balance of payments problems, though issues have also been raised regarding the possibility of immiserising growth, principally in cases of a large exporting country or export boom of a particular type of product involving several exporting countries. Further benefits are expected if subsidies hitherto placed on goods to stimulate their exports are reduced or removed as this reduction or removal then lowers or eliminates the distortion losses from production and consumption.

For a typical developing country like Nigeria, the concerns have gravitated around the costs and benefits associated with import liberalization in the form of reducing the number of prohibited goods and subjecting them to tariffs and reduction of existing high tariffs. Hence, import liberalization benefits include the expansion of supply base, including access to intermediate materials, lower prices, efficiency-inducing competition to local industries, and the development of export firms which seeks trading opportunity in a more open economy. Thus, export diversification constitutes a dynamic gain from import liberalisation, along with capital accumulation through domestic and foreign investment, stimulus to competition, transmission and acquisition of new technical and business knowledge and changes in attitudes and institutions (Thirlwall, 2003, p.630). Increased income and consumption are the final long-term gains of import liberalisation, resulting from dynamic gains of trade and manifested as an improvement of the economy's long-run growth. Where the liberalization takes the form of tariffication of import prohibitions or quotas, reduction of government revenue normally postulated may not occur and liberalization of this sort will turn out to be beneficial to the extent that it contributes to government revenue.

In the case of the reform of the investment environment, this constitutes a policy design following the expectation of reaping such benefits as job creation, technology transfer, improved corporate governance in terms of better management practices, capital formation, expanded market access, increased product diversity and total productivity growth (see Coe, Helpman and Hoffmaister, 1997; Borensztein, De Gregorio and Lee, 1995; de Mello, 1997). These claims have not been without some measure of pessimism, especially as they relate to the impact of foreign direct investment on growth, which most investment reforms target. Devarajan, Easterly and Pack (2003) are of the view that in the absence of several underlying fundamentals, such as high capacity utilisation, good policies and high absorptive capacity of induced-skill acquisition opportunities created by the foreign direct investment, a higher level of investment will not in itself lead to a higher GDP growth rate. Where the foreign direct investment lacks appropriate backward linkages in the host economy, especially the case of inadequate sourcing of inputs and intermediate materials from local suppliers, the positive impact on growth occurs with a lag, and in effect, is slow (Akinlo 2004). The inconclusive evidence of the relationship between foreign direct investment and growth may have additionally been due to a number of factors namely, the proneness of foreign direct investment to widen 
rural-urban income inequality, its encouragement of wasteful consumption, and introduction of inappropriate technology which tends to crowd out or slow down the development of indigenous capital goods industry and stifle indigenous entrepreneurship (Thirlwall 2003).

\section{Methodology of the Study}

\section{IV.1 Model Specification}

A formal empirical framework for deriving the determinants of output growth in which economic policy, particularly trade and investment policies are included is developed. The initial step in the process is the specification of an explicit Cobb-Douglas production function of the usual form as follow:

$$
\begin{aligned}
& \mathrm{Q}=A K^{\mathrm{a}} \mathrm{L}^{\mathrm{b}} \\
& \mathrm{A}=\mathrm{A}(0) \mathrm{E}^{\mathrm{it}}
\end{aligned}
$$

Where $\mathrm{Q}$ is the value added, $\mathrm{K}$ and $\mathrm{L}$ are measures of capital and labour services, while $\mathrm{A}$ is the measures of efficiency and total factor productivity growth (TFPG) which are linearly related to trade and investment policy regime. Substituting equation (1b) in (1a), we have;

$$
\mathrm{Q}=\mathrm{AK}^{\mathrm{a}} \mathrm{L}^{\mathrm{b}}\left[\mathrm{A}(0) \mathrm{E}^{\mathrm{it}}\right]
$$

differentiating equation (2) totally;

$$
d Q=a(d Q / d K) d K+b(d Q / d L) d L+i t(d Q / d A t) d A t
$$

Taking the growth rate of equation (3), we have;

$$
\begin{aligned}
\mathrm{dQ} / \mathrm{Q} & =\mathrm{a}(\mathrm{dQ} / \mathrm{dK})(\mathrm{dK} / \mathrm{K})+\mathrm{b}(\mathrm{dQ} / \mathrm{dL})(\mathrm{dL} / \mathrm{L})+\mathrm{it}\left(\mathrm{dQ} / \mathrm{dA}_{\mathrm{t}}\right)\left(\mathrm{dA}_{\mathrm{t}} / \mathrm{A}_{\mathrm{t}}\right) \\
\mathrm{q} & =\mathrm{x}_{0}+\mathrm{e}_{1} \mathrm{k}+\mathrm{e}_{2} \mathrm{l}+\mathrm{e}_{3} \mathrm{a}
\end{aligned}
$$

Where $\mathrm{q}$ is the growth rate of output, $\mathrm{k}$ and $\mathrm{l}$ are growth rates of measures of capital and labour services, while components of (a) are measures of growth rate of total productivity of factors which are assumed linearly associated with measures of trade and investment policy (t and i) and a(dQ/dK), b(dQ/dL) $i\left(d Q / d A_{t}\right.$ ) can be termed as measures of marginal productivity of factor inputs $\left(\mathrm{e}_{\mathrm{i}}\right)$. Equation (4) implies that, apart from growth of capital and labour, economic policy regimes, particularly trade and investment policy regimes influence output growth through efficiency and technical change which jointly generate TFPG. In order to investigate the impact of trade policy on output growth performance of the economy equation (4) is reduced to the following:

$$
q=x_{0}+e_{1} k+e_{2} l+e_{3} a+R
$$

where $\mathrm{R}$ is the random variable or error term which capture the impact of other variables not included in the model and $\mathrm{x}_{0}$ is the constant term. Empirical measures of trade and investment policy regime (a) adopted in this study are growth of openness measures which are imports- and exports-GDP ratio (mgdpgrowth and xgdpgrowth), while dummy variables TRDPREFdum and INVPREFdum are used to reflect the changes in the trade and investment regimes or reforms. Growth rate of capital (investment) and labour force are denoted by gfcfGrowth and lfgrowth. 
Thus, the equation to be estimated can be expressed as

$\mathrm{q}=\mathrm{x}_{0}+\mathrm{e}_{1}$ gfcfGrowth $+\mathrm{e}_{2}$ lfgrowth $+\mathrm{e}_{3} \mathrm{xgdpgrowth}+\mathrm{e}_{4}$ mgdpgrowth

$+\mathrm{e}_{5}$ TRDPREFdumm $+\mathrm{e}_{6}$ INVPREFdumm $+\mathrm{R}$

Since trade policy influences investment through export and import, an aggregate production function which decomposes aggregate output into tradeable and non-tradeable (as in Feder 1982) can be rewritten as

$$
\begin{gathered}
\mathrm{Q}=\mathrm{Xe}+\mathrm{Xn} \\
\mathrm{Q}\left(\mathrm{AK}^{\mathrm{a}} \mathrm{L}^{\mathrm{b}}\right)=\mathrm{Xe}\left(\mathrm{AK}^{\mathrm{a}} \mathrm{L}^{\mathrm{b}}\right)+\mathrm{Xn}\left(\mathrm{AK}^{\mathrm{a}} \mathrm{L}^{\mathrm{b}}\right) \\
\mathrm{Xe}=\mathrm{f}\left(\mathrm{AK}^{\mathrm{a}} \mathrm{L}^{\mathrm{b}}\right) \\
\mathrm{Xn}=\mathrm{f}\left(\mathrm{AK}^{\mathrm{a}} \mathrm{L}^{\mathrm{b}} \mathrm{Xe}\right)
\end{gathered}
$$

Following the above steps tradeable (Xe) and non-tradeable (Xn) functions can be written as:

$$
\begin{aligned}
& \mathrm{X}_{\mathrm{e}}=\mathrm{x}_{0}+\mathrm{e}_{1} \text { gfcfGrowth }+\mathrm{e}_{2} \text { lfgrowth }+\mathrm{e}_{3} \text { REFRgrowth }+\mathrm{e}_{4} \text { mgdpgrowth }+\mathrm{e}_{5} \text { TRDPREFdum }+ \\
& \quad \mathrm{e}_{6} \text { TOTgrowth } \ldots \ldots .(7) \\
& \mathrm{X}_{\mathrm{n}}=\mathrm{x}_{0}+\mathrm{e}_{1} \text { gfcfGrowth }+\mathrm{e}_{2} \text { Ifgrowth }+\mathrm{e}_{3} \text { REFRgrowth }+\mathrm{e}_{4} \text { xgdpgrowth }+\mathrm{e}_{5} \text { mgdpgrowth }+ \\
& \quad \mathrm{e}_{6} \text { TRDPREFdumm }+\ldots \ldots(8) \\
& \mathrm{M}=\mathrm{x}_{0}+\mathrm{e}_{1} \text { REFRgrowth }+\mathrm{e}_{2} \text { TOTgrowth }+\mathrm{e}_{3} \text { gdpgrowth ......... (9) }
\end{aligned}
$$

Following the accelerator principle, there exists a technical relationship between a given level of output produced and capital stock required to produce that given level of output. This relationship is usually expressed as:

$$
\mathrm{K}_{\mathrm{t}}-\mathrm{K}_{\mathrm{t}-1}=\mathrm{h}\left(\mathrm{Y}_{\mathrm{t}}-\mathrm{Y}_{\mathrm{t}-1}\right)
$$

Expressing in growth terms we

$$
\left(\mathrm{K}_{\mathrm{t}}-\mathrm{K}_{\mathrm{t}-1}\right) / \mathrm{K}_{\mathrm{t}}=\mathrm{h}\left(\mathrm{Y}_{\mathrm{t}}-\mathrm{Y}_{\mathrm{t}-1}\right) / \mathrm{Y}_{\mathrm{t}}
$$

Following the decomposition of output into tradeable and non-tradeable and measuring in growth terms we have

$$
\begin{gathered}
\left(\mathrm{K}_{\mathrm{t}}-\mathrm{K}_{\mathrm{t}-1}\right) / \mathrm{K}_{\mathrm{t}}=\mathrm{h}\left\{\left(\mathrm{Xe}_{\mathrm{t}}-\mathrm{Xe}_{\mathrm{t}-1}\right) / \mathrm{Xn}_{\mathrm{t}}:\left(\mathrm{Xn}_{\mathrm{t}}-\mathrm{Xn}_{\mathrm{t}-1}\right) / \mathrm{Xn}_{\mathrm{t}}\right\} \\
\mathrm{k}=\mathrm{h}\left(\mathrm{X}_{\mathrm{e}}, \mathrm{X}_{\mathrm{n}}\right)
\end{gathered}
$$

where lower case letters denote growth rates. Including other determinants of investment such as real interest rate (RINTR), external debt-GDP ratio (EXTDGDP), fiscal deficit-GDP ratio (DEFGDP) in the equation yields:

$\mathrm{k}=\mathrm{x}_{0}+\mathrm{e}_{1}$ xegrowth $+\mathrm{e}_{2}$ xngrowth $+\mathrm{e}_{3}$ EXTDGDPgrowth $+\mathrm{e}_{4}$ DEFGDPgrowth $+\mathrm{e}_{5}$ TRDPREFdum + $\mathrm{e}_{6}$ INVPREFdumm $+\mathrm{R}$

Equations (6) - (10) are adopted for sectoral analyses which cover agriculture, manufacturing and services. 


\section{IV.2 Estimation techniques and Data Sources}

Apart from generating the magnitude of association between output growth and export and import growth, either of agriculture, manufacturing and services, dummies capturing trade and investment policy regimes included in the equations should help disentangle reform effects on economic growth. The estimation method used is the ordinary least squares (OLS), having been constrained by inadequate data series to apply the full information maximum likelihood (FIML) estimator which is deemed ideal for the system of equations specified. Since a recent effort in this direction did not also yield significant differences between OLS and FIML estimates (Oyejide, Ogunkola and N'juguna, 2002), it is believed that the OLS estimates in this study can be relied upon.

Data were gathered from the publications of the World Bank. This includes the World Development Indicators and African Development Indicators. The data used were measured in real terms.

\section{Empirical Analysis}

Five equations were estimated for aggregate output growth, and for each of the manufacturing, agricultural and services output growths. Table 5.1 indicates the results for the aggregate output growth equations. While labour force growth turns out to be of wrong sign though not statistically significant, the growth of investment, import share, export share, and foreign direct investment ratio are rightly signed and significant. Dummies for trade and investment policies are not significant perhaps because the variables they impact in the first stage of the transmission process are included in the model. For the investment growth equation, the growth of the non-export sector as well as that of one-period lag of investment are statistically significant and of the right signs. Three variables are statistically significant in the export growth equation. These are the non-export sector growth, terms of trade, and average tariff. The first two are positively signed while growth of average tariff carries a negative sign, suggesting that a higher tariff brings about a lower export growth, confirming that a tax on imports is also a tax on exports. The investment policy reform appears to have influenced more the non-export sector as the associated coefficient is positive and significant. So also are the variables measuring investment and labour force growth. In the aggregate import growth equation, trade policy reform and one-period lag of output growth are the rightly signed and statistically significant variables.

Table 5.1: Aggregate Output Growth

\begin{tabular}{|llllll||}
\hline \hline & $\begin{array}{l}\text { Aggregate } \\
\text { output } \\
\text { Drowth }\end{array}$ & $\begin{array}{l}\text { Aggregate } \\
\text { investment } \\
\text { growth }\end{array}$ & $\begin{array}{l}\text { Aggregate } \\
\text { export } \\
\text { Growth }\end{array}$ & $\begin{array}{l}\text { Aggregate } \\
\text { non- } \\
\text { export } \\
\text { Growth }\end{array}$ & $\begin{array}{l}\text { Aggregate } \\
\text { import } \\
\text { Growth }\end{array}$ \\
\hline Independent Variable & & & & & \\
Constant & 19.01 & 5.09 & 116.19 & -78.68 & 16.21 \\
& -1.59 & -0.96 & -0.72 & $-(2.49)^{*}$ & $(2.57)^{*}$ \\
Labour force growth & -6.41 & & -39.14 & 27.68 & \\
\hline \hline & -1.5 & & -0.69 & $(2.45)^{*}$ & \\
Aggregate investment growth & 0.1 & & -0.27 & 0.55 & \\
Aggregate import share & $(4.34)^{*}$ & & -1.01 & $(7.11)^{*}$ & -0.31 \\
Growth & -0.1 & & & -2.6 & \\
Aggregate export & $-(1.99)^{*}$ & & & 0.11 &
\end{tabular}




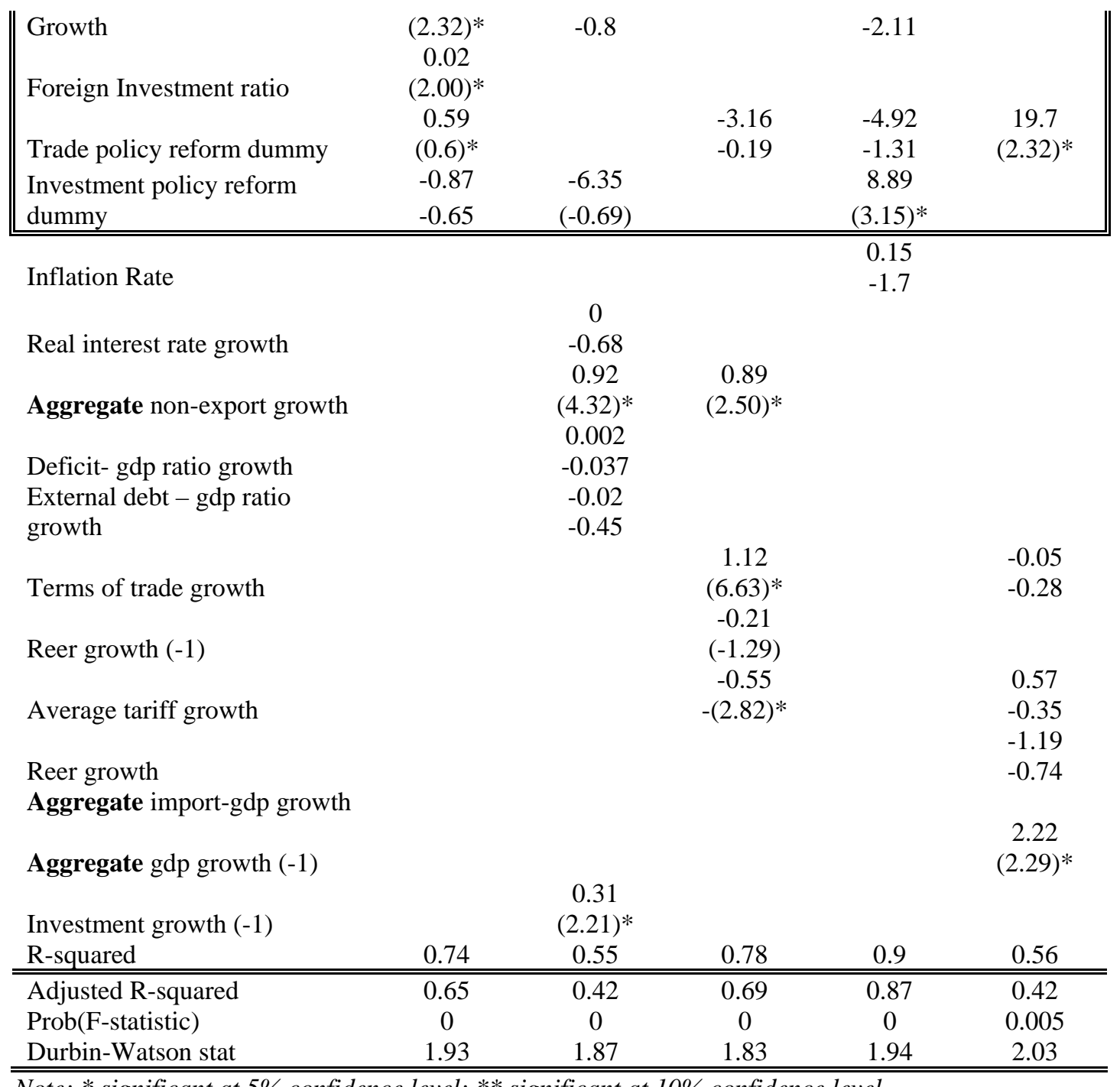

Note: * significant at 5\% confidence level; ** significant at $10 \%$ confidence level

Table 5.2 presents similar estimates for the agriculture sector. Labour force growth, and foreign investment are negatively signed while agricultural export growth is rightly signed and significant.

Table 5.2 Agriculture Output Growth

\begin{tabular}{|c|c|c|c|c|c|}
\hline Dependent variable & $\begin{array}{l}\text { Agric } \\
\text { output } \\
\text { Growth }\end{array}$ & $\begin{array}{l}\text { Agric } \\
\text { investment } \\
\text { growth }\end{array}$ & $\begin{array}{l}\text { Agric } \\
\text { export } \\
\text { Growth }\end{array}$ & $\begin{array}{l}\text { Agric } \\
\text { non- } \\
\text { export } \\
\text { Growth }\end{array}$ & $\begin{array}{l}\text { Agric } \\
\text { import } \\
\text { Growth }\end{array}$ \\
\hline \multicolumn{6}{|l|}{ Independent Variable } \\
\hline \multirow{3}{*}{ Constant } & 43.57 & 108.43 & 40.02 & 38.2 & 29.44 \\
\hline & $(2.11)^{*}$ & $(4.23)^{*}$ & -0.11 & -0.61 & $(6.67)^{*}$ \\
\hline & -16.14 & & -5.39 & -13.93 & \\
\hline Labour force growth & $-(2.23)^{*}$ & & $(-0.04)$ & -0.61 & \\
\hline \multirow[b]{2}{*}{ Agric investment growth } & 0.007 & & -0.27 & -0.11 & \\
\hline & -0.71 & & $(-2.27)^{*}$ & $-(3.10)^{*}$ & \\
\hline Agric import & 0.007 & & & 0.24 & \\
\hline Growth & -0.54 & & & $(3.27)^{*}$ & \\
\hline Agric export & 0.04 & & & -0.04 & \\
\hline \multirow[t]{2}{*}{ Growth } & $(2.52)^{*}$ & & & -0.7 & \\
\hline & -0.01 & & & & \\
\hline Foreign Investment ratio & $-(2.82)^{*}$ & & & & \\
\hline Agric export & & -0.64 & & & \\
\hline Growth & & $-(3.33)^{*}$ & & & \\
\hline
\end{tabular}




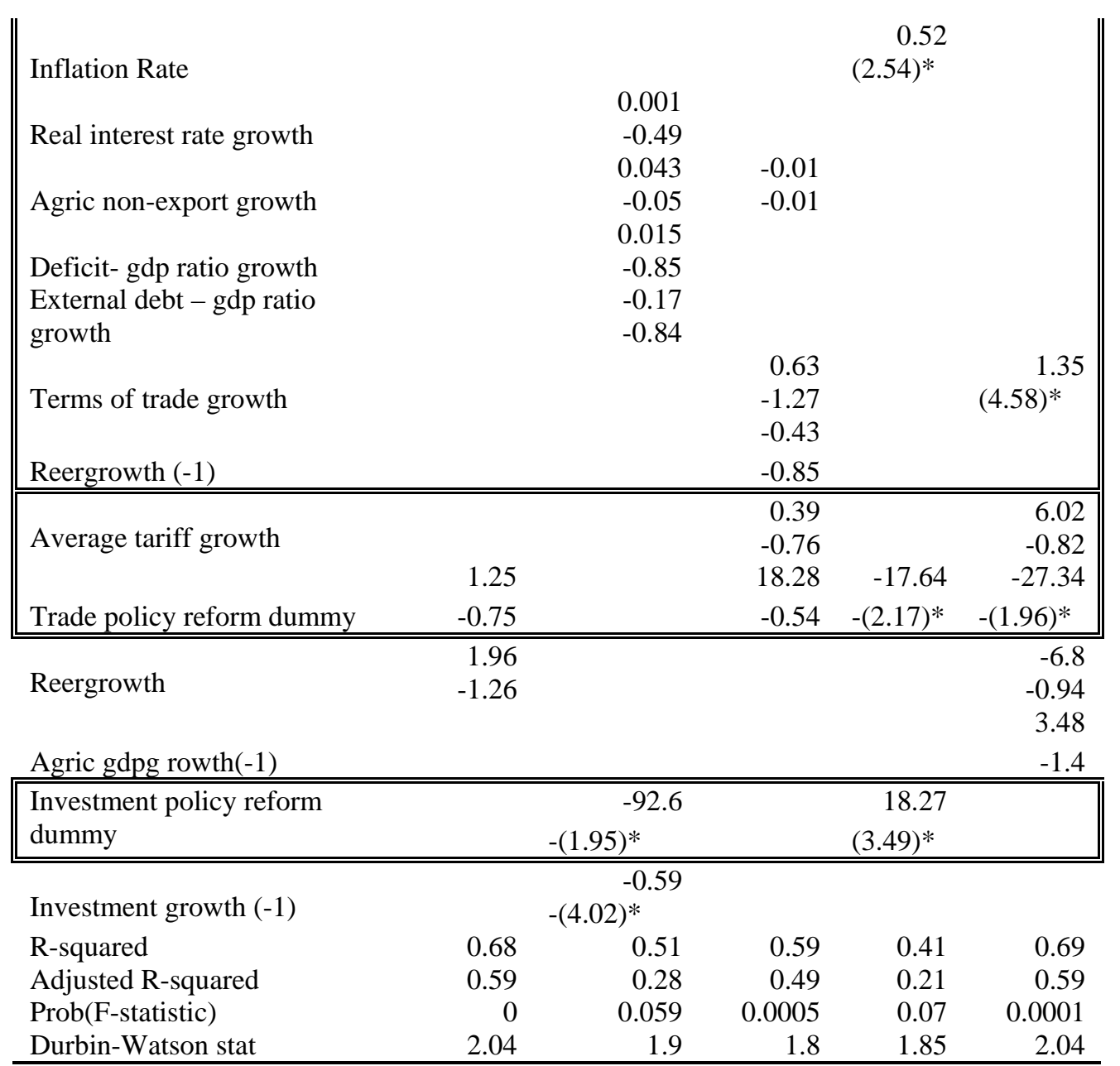

Note: * significant at 5\% confidence level; ** significant at $10 \%$ confidence level; $t$-statistics are in parenthesis

Agricultural investment growth is of the wrong sign in the agriculture export and non-export growth equations. Growth of imports in agriculture is positively and significantly associated with non-export sector. On one hand, trade policy reform impacts significantly on non-export agriculture and agriculture imports. On the other, investment policy reform influences significantly the agriculture investment and non-export sector.

Trade and investment policy reforms do not appear to have significantly affected the manufacturing sector (Table 5.3). Specifically, manufacturing investment growth is positively related to manufacturing output growth but negatively associated with the sector's export and non-export growths. The trade policy reform dummy significantly affects manufacturing output growth while the investment policy reform dummy is not. However, manufacturing investment growth is positively and significantly influenced by its one-period lag.

In the case of the services sector, services investment growth, services import growth, and foreign direct investment growth are variables that significantly affect services output growth (Table 5.4). It is not surprising that trade policy reform did not appear to influence services output growth, the dummy is only able to measure trade restrictiveness or otherwise in merchandise trade directly. Nonetheless, trade policy reform generally has contributed significantly and positively to services export and import growth. Investment policy, on the other hand, contributes to the growth of the non-export services sector. 
Table 5.3: Manufacturing Output Growth

\begin{tabular}{|c|c|c|c|c|c|}
\hline Dependent variable & $\begin{array}{l}\text { Manufacturing } \\
\text { output } \\
\text { Growth } \\
\end{array}$ & $\begin{array}{l}\text { Manufacturing } \\
\text { investment } \\
\text { growth }\end{array}$ & $\begin{array}{l}\text { Manufacturing } \\
\text { export } \\
\text { Growth } \\
\end{array}$ & $\begin{array}{l}\text { Manufacturing } \\
\text { non-export } \\
\text { Growth } \\
\end{array}$ & $\begin{array}{l}\text { Manufacturing } \\
\text { import } \\
\text { Growth } \\
\end{array}$ \\
\hline \multicolumn{6}{|l|}{ Independent Variable } \\
\hline Constant & $\begin{array}{l}68.36 \\
(1.23)\end{array}$ & $\begin{array}{c}16.56 \\
(1.91)^{* *}\end{array}$ & $\begin{array}{l}52.31 \\
(1.6)\end{array}$ & $\begin{array}{l}141.2 \\
(0.89)\end{array}$ & $\begin{array}{l}12.54 \\
(2.50)^{*}\end{array}$ \\
\hline Labour force growth & $\begin{array}{l}-22.42 \\
-(1.14) \\
\end{array}$ & & & $\begin{array}{r}-40.86 \\
(0.73)\end{array}$ & \\
\hline Manufacturing investment growth & $\begin{array}{c}0.15 \\
(2.21)\end{array}$ & & $\begin{array}{c}-0.56 \\
-(1.82)^{* *}\end{array}$ & $\begin{array}{c}-0.44 \\
-(3.2)^{*}\end{array}$ & \\
\hline Manufacturing import Growth & $\begin{array}{c}0.04 \\
(0.45)\end{array}$ & & & & \\
\hline Manufacturing export Growth & $\begin{array}{c}0.05 \\
(1.12)\end{array}$ & $\begin{array}{l}-0.05 \\
-(0.81)\end{array}$ & & & \\
\hline Foreign Investment ratio & $\begin{array}{l}-0.04 \\
-(1.46)\end{array}$ & & & & \\
\hline Trade policy reform dummy & $\begin{array}{c}-13.9 \\
-(2.64)^{*}\end{array}$ & & $\begin{array}{c}-33.1 \\
-(0.82)\end{array}$ & $\begin{array}{l}-29.8 \\
-(1.39)\end{array}$ & $\begin{array}{c}-3.32 \\
-(0.66)\end{array}$ \\
\hline Investment policy reform dummy & $\begin{array}{c}5.61 \\
(1.32) \\
\end{array}$ & $\begin{array}{c}-0.29 \\
-(0.02) \\
\end{array}$ & & $\begin{array}{c}-4.28 \\
-(0.20) \\
\end{array}$ & \\
\hline \multicolumn{6}{|l|}{ Manufacturing export Growth } \\
\hline Inflation Rate & & $\begin{array}{c}0.76 \\
(3.41)\end{array}$ & & $\begin{array}{l}0.195 \\
(0.55)\end{array}$ & \\
\hline Real interest rate growth & & $\begin{array}{l}-0.002 \\
-(2.64)\end{array}$ & & & \\
\hline Manufacturing non-export growth & & $\begin{array}{c}-0.33 \\
-(2.44)^{*}\end{array}$ & $\begin{array}{c}0.38 \\
(1.14)\end{array}$ & & \\
\hline Deficit- gdp ratio growth & & $\begin{array}{c}-0.02 \\
-(1.91)^{* *}\end{array}$ & & & \\
\hline External debt - gdp ratio growth & & $\begin{array}{l}-0.03 \\
(0.53)\end{array}$ & & & \\
\hline Terms of trade growth & & & $\begin{array}{l}0.017 \\
(0.06)\end{array}$ & & $\begin{array}{c}0.71 \\
(3.53)^{*}\end{array}$ \\
\hline Refxgrowth (-1) & & & $\begin{array}{c}1.55 \\
(3.66)^{*}\end{array}$ & & \\
\hline Average tariff growth & & & $\begin{array}{c}0.98 \\
(1.99)^{*}\end{array}$ & & $\begin{array}{c}1.33 \\
(0.51)\end{array}$ \\
\hline REFXGROWTH & & & & & $\begin{array}{l}-2.10 \\
-(0.85)\end{array}$ \\
\hline $\begin{array}{l}\text { Manufacturing import-GDP } \\
\text { GROWTH }\end{array}$ & & & & $\begin{array}{c}-0.16 \\
-(3.32)^{*}\end{array}$ & \\
\hline Manufacturing GDP GROWTH & & & & & $\begin{array}{c}-0.23 \\
-(0.49)\end{array}$ \\
\hline Investment growth $(-1)$ & & $\begin{array}{c}0.66 \\
(4.53)^{*}\end{array}$ & & & \\
\hline R-squared & 0.58 & 0.35 & 0.33 & 0.57 & 0.49 \\
\hline Adjusted R-squared & 0.44 & 0.09 & 0.13 & 0.39 & 0.34 \\
\hline Prob(F-statistic) & 0.003 & 0.25 & 0.16 & 0.02 & 0.012 \\
\hline Durbin-Watson stat & 1.99 & 1.69 & 1.78 & 2.03 & 2.05 \\
\hline
\end{tabular}

Note: * significant at $5 \%$ confidence level; ** significant at $10 \%$ confidence level; $t$-statistics are in parenthesis 


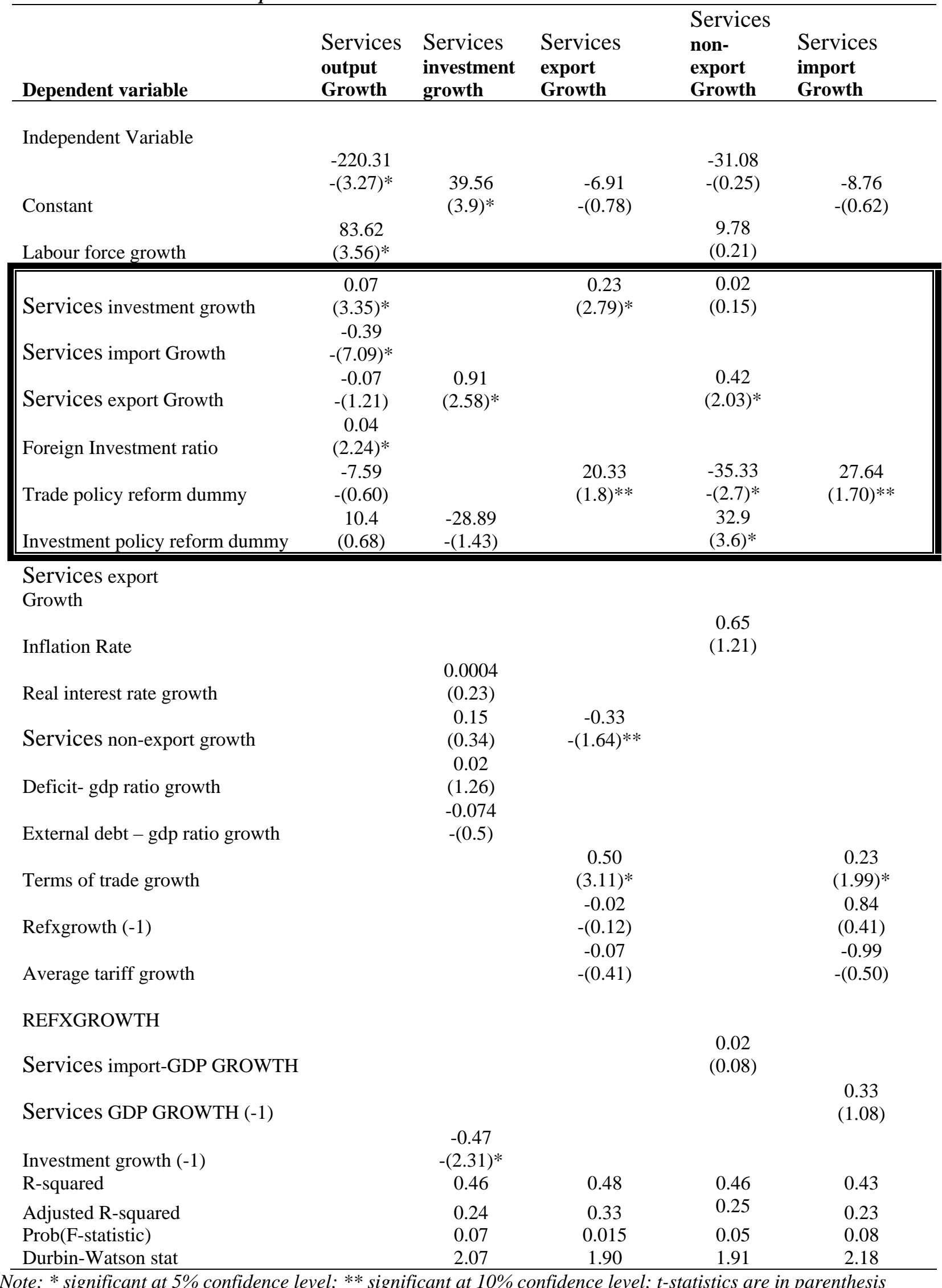

Note: * significant at 5\% confidence level; ** significant at 10\% confidence level; $t$-statistics are in parenthesis 
The totality of sectoral activities determines the level of aggregate activities. Based on this, the impact of trade and investment policy reforms on sectoral growth performance would eventually show up in the aggregate growth performance. While different sectors may respond to trade and investment policy reforms differently, trade and investment policy reform measures implemented in each sector is likely to be different. It is therefore considered necessary to examine the impact of trade and investment policy reform measures undertaken in each sector on aggregate growth performance. This will enable us to see how different sectoral policy reforms impact on the performance of the entire economy. Thus, it is possible to discern which sectoral policy reform measures have the greatest or least potential to generate positive impact on aggregate growth. The result of this kind of exercise can inform policy decisions on resource allocation for growth of the economy. This implies that, the sector(s) that has (or have) higher potential to generate more positive impact on aggregate growth may be accorded more priority in the allocation of resources.

Sectoral analysis is attempted by incorporating sectoral policy reform variables into the aggregate growth model (Aq) as follows;

$\mathrm{Aq} \quad=\quad \mathrm{f}$ (Mgrowth, Agrowth, Sgrowth)

Where, Mgrowth, Agrowth and Sgrowth denote sectoral growth performance in the Manufacturing, Agricultural and Services services, each of which has been earlier said to be influenced by factors such as sectoral inputs growth and trade and investment policy variables at sectoral level. Thus, instead of using the aggregate policy variables in the aggregate growth model, sectoral variables are substituted. This additional model was estimated for each sector.

In order to assess the possible impact of trade and investment policy reforms on the economy, additional equations which were subsequently used for forecasting and simulations were estimated. Table 5.5 shows the results of these estimations for agriculture, manufacturing and services sectors. Agricultural investment growth affects the economy positively though not statistically significantly, unlike services investment growth whose contribution to the economy is significant and positive.

The growth of manufacturing investment appears to impact negatively on economy. While services import growth affects the economy positively and in a significant way, agricultural and manufacturing import growths affect it in the opposite direction. Before analysing the future impacts of trade and investment policy reforms on output, presented on Table 5.7, Table 5.6 provides the Theil Inequality index for the equations used for simulations. The underlying assumption is that these reforms will generate growth in import and export of agriculture, manufactures and services between 2005 and 2008 by between 10\%50\%. The forecast statistics in Table 5.6 appear acceptable. In particular, the bias proportions are very small.

Following increase in export shares and import shares as a result of trade and investment policy reforms, the GDP is expected to grow on the average by 4.8\% in 2005, and by about 5\% in 2006 and 2007 and 5.4\% in 2008. These growth rates result from the average of the sectoral stimuli on growth. In particular, the effect of investment and trade policy reforms on the manufacturing sector provides the largest stimulus for economic growth while that of the agricultural sector dampens the economy's growth potentials. For the 
services sector, effect of reforms on the sector provides a moderate stimulus for growth between 2005 and 2008.

Table 5.5: Trade and Investment Reforms: Sectoral Output Responses and Aggregate Output Growth

\begin{tabular}{|c|c|c|c|}
\hline Dependent variable & Aggregate o & tput Growth & \\
\hline Independent Variable & Agriculture & Manufacturing & Services \\
\hline Constant & $\begin{array}{r}-20.15 \\
-(0.7)\end{array}$ & $\begin{array}{r}-47.66 \\
-(1.6)\end{array}$ & $\begin{array}{r}36.89 \\
(2.65)^{* *}\end{array}$ \\
\hline Labour force growth & $\begin{array}{r}-5.89 \\
-(0.56) \\
\end{array}$ & $\begin{array}{r}-15.7 \\
-(1.48) \\
\end{array}$ & $\begin{array}{r}-12.92 \\
-(2.58)^{*}\end{array}$ \\
\hline investment growth & $\begin{array}{r}0.01 \\
-(1.33)\end{array}$ & $\begin{array}{r}-0.06 \\
-(1.79)^{* *}\end{array}$ & $\begin{array}{r}0.02 \\
(1.87)^{* *}\end{array}$ \\
\hline Import Growth & $\begin{array}{r}-0.03 \\
-(2.98)\end{array}$ & $\begin{array}{r}-0.02 \\
-(0.85)\end{array}$ & $\begin{array}{r}0.04 \\
(1.88)^{* *}\end{array}$ \\
\hline Export Growth & $\begin{array}{r}0.014 \\
(2.10)^{*}\end{array}$ & $\begin{array}{r}0.05 \\
(3.15)^{*}\end{array}$ & $\begin{array}{r}0.04 \\
-(1.46)\end{array}$ \\
\hline Foreign Investment ratio & $\begin{array}{r}0.004 \\
-(0.5) \\
-3.19\end{array}$ & $\begin{array}{r}-0.004 \\
-(0.5) \\
-4.87\end{array}$ & \\
\hline Trade policy reform dummy & $-(0.88)$ & $-(1.5)$ & \\
\hline $\begin{array}{l}\text { Investment policy reform } \\
\text { dummy }\end{array}$ & $\begin{array}{r}0.41 \\
-(0.12) \\
\end{array}$ & $\begin{array}{r}3.23 \\
-(0.94) \\
\end{array}$ & $\begin{array}{r}-2.67 \\
-(2.65) \\
\end{array}$ \\
\hline R-squared & 0.72 & 0.55 & 0.8 \\
\hline Adjusted R-squared & 0.63 & 0.39 & 0.7 \\
\hline Prob(F-statistic) & 0.0 & 0.01 & 0 \\
\hline Durbin-Watson stat & 2.23 & 2.09 & 2.5 \\
\hline
\end{tabular}

Table 5.6: Forecast statistics

Theil Inequality coefficient

$\begin{array}{lrrr} & \text { Agriculture } & \text { Manufacturing } & \text { Services } \\ \text { Theil Inequality coefficient } & 0.59 & 0.49 & 0.45 \\ \text { Bias Proportion } & 0.01 & 0.01 & 0.02 \\ \text { Variance } & & & \\ \text { proportion } & 0.41 & 0.22 & 0.12 \\ \text { Covariance Proportion } & 0.57 & 0.75 & 0.86\end{array}$

Source: Computed by authors

Table 5.7: Forecast GDP Growth (2005-2008)

\begin{tabular}{lrrrr} 
& 2005 & 2006 & 2007 & 2008 \\
\cline { 2 - 5 } Agriculture & \multicolumn{4}{c}{ Aggregate GDP Growth (\%) } \\
\cline { 2 - 5 } Manufacturing & 2.4 & 2.2 & 2.0 & 2.0 \\
Services & 7 & 7.3 & 7.5 & 7.7 \\
Average & 5.1 & 5.5 & 5.9 & 6.5 \\
& 4.8 & 5.0 & 5.1 & 5.4
\end{tabular}

Source: Computed by authors 


\section{Summary of findings, Policy implications and Conclusion}

The results show that labour force growth is not a significant determinant of aggregate output growth, while the growth of investment, import share, export share, and foreign direct investment ratio are major factors influencing aggregate output growth. It was shown that trade and investment policy reforms do not have significant impact on aggregate output growth. Result further reveals that growth of non-export as well as previous level of investment is significant determinants of aggregate investment in Nigeria. Moreover, among the significant determinants of export growth are non-export growth, terms of trade, and average tariff. The growth of average tariff carries a negative sign, suggesting that a higher tariff brings about a lower export growth, confirming that a tax on imports is also a tax on exports.

Empirical result shows that investment policy reform appears to have influenced the non-export growth. So also are the variables measuring investment and labour force growth. It was seen that, trade policy reform and one-period lag of output growth produced positive impact on aggregate import growth.

Sectoral results reveal that, in the case of agriculture sector, labour force growth, and foreign investment have negative impact on agricultural output growth while agricultural export growth has positive impact on same. Further, agricultural investment growth hindered export and non-export growth in the sector. Growth of imports has positive and significant impact on non-export growth. On one hand, trade policy reform impacts significantly on non-export and imports in the sector. On the other, investment policy reform influences significantly the agriculture investment and non-export sector.

Manufacturing investment growth is positively related to manufacturing output growth but negatively associated with the sector's export and non-export growths. Trade policy reform significantly affects manufacturing output growth while the investment policy reform is not. However, manufacturing investment growth is positively and significantly influenced by its previous level.

In the case of the services sector, investment growth, import growth, and foreign direct investment growth in the sector significantly affect services output growth. It is not surprising that trade policy reform did not appear to influence services output growth because it is not directed at the sector. Nonetheless, trade policy reform generally has contributed significantly and positively to services export and import growth. Investment policy, on the other hand, contributes to the growth of the non-export services sector.

The impact of trade and investment policy reforms on sectoral growth performance would eventually show up in the aggregate growth performance. It should be noted that different sectors may respond to trade and investment policy reforms differently. It should also be noted that trade and investment policy reform measures implemented in each sector is likely to be different. It is therefore considered necessary to examine the impact of trade and investment policy reform measures undertaken in each sector on aggregate growth performance. This will enable us to see how different sectoral policy reforms impact on the performance of the entire economy. Thus, we would be able to see which sectoral policy reform measures have the greatest or least potential to generate positive impact on aggregate growth. The result of this kind of exercise can inform policy decisions on resource allocation for growth of the economy. This implies that, the sector(s) that has (or have) higher potential to generate more positive impact on aggregate growth may be accorded more priority in the allocation of resources. 
Results reveal that agricultural investment growth affects the economy positively but insignificantly, while services investment growth contributes positively and significantly to the economy. The growth of manufacturing investment appears to impact negatively on economy. While services import growth affects the economy positively and significantly, agricultural and manufacturing import growths affect it in the opposite direction.

The simulation experiments show that, following increase in export shares and import shares as a result of trade and investment policy reforms, the GDP is expected to grow on the average by $4.8 \%$ in 2005 , and by about 5\% in 2006 and 2007 and 5.4\% in 2008. These growth rates result from the average of the sectoral stimuli on growth. In particular, the effect of investment and trade policy reforms on the manufacturing sector provides the largest stimulus for economic growth while that of the agricultural sector dampens the economy's growth potentials. For the services sector, effect of reforms on the sector provides a moderate stimulus for growth between 2005 and 2008. 


\section{Bibliography}

Adenikinju A., (2005), 'African Imperatives in the New World Trade Order: The Case of Manufacturing' In E.O Ogunkola and A. S. Bankole (eds.), Nigeria's Imperatives in a New World Trade Order, Trade Policy Research and Training Programme Department of Economics, University of Ibadan and AERC, Nairobi.

Adewuyi, A.O. (2001), "The Implications of Crude Oil Exploitation and Export on the Environment and Level of Economic Growth and Development in Nigeria”. Proceedings of the annual Conference of the Nigerian Economic Society.

Agbaje A. and A. Jerome (2005). 'Institutional Framework for Trade Policy in Nigeria' In E.O Ogunkola and A. S. Bankole (eds.), Nigeria's Imperatives in a New World Trade Order, Trade Policy Research and Training Programme Department of Economics, University of Ibadan and AERC, Nairobi.

Akinlo, A 2004. "Foreign direct investment and growth in Nigeria An empirical investigation" Journal of Policy Modeling 26: 627-39

Amjadi, A., U. Reinke and A. Yeast (1996), Did External Barriers Cause the Marginalisation of Sub-Saharan African in World Trade? World Bank, Washington, DC.

Baldwin, R. E. (2003), “Openness and Growth: What's the Empirical Relationship?” NBER Working Paper Number 9576. National Bureau of Economic Research, Cambridge, Massachusetts. March. http://www.nber.org/papers/w9578

Baldwin, R. E. and E. Seghezza (1996), "Trade-Induced Investment-Led Growth", CEPR Discussion Paper Series, No 1430, June, CEPR, London.

Bankole, A. S (2004b), "An Econometric Analysis of Firms Compliance Costs of Sanitary and PhytoSanitary Standards (SPS) in Nigeria’s Export Markets: The case of Processed Agricultural and Food Products”. African Journal of Economic Policy,_10 (2), December, pp. 103-136.

Bankole, A.S (2004a), "Sanitary and PhytoSanitary Standards and Processed Agricultural and Food Products Exports. Evidence from Nigerian Firms”. African Journal of Economic Policy, 10 (1), June, pp.33-54.

Bankole, A.S and K. Olayiwola (2001), Policy and Institutional Arrangements for Promoting Industrial Development, DPC Research Report No 31, Ibadan, Development Policy Centre.

Boeninger, E. (1991), “Governance and Development: Issues and Constraints. Proceedings of the World Bank Annual Conference on Development Economics, World Bank, Washington, DC.

Borensztein, E., J. De Gregorio and J.-W. Lee (1995) 'How Does Foreign Investment Affect Growth?', NBER Working Paper, 5057 (Cambridge: mass: NBER).

Busse, M., A. Borrmann, and H. Grobmann (2004), "The Impact of ACP-EU Economic Partnership Agreements on ECOWAS Countries: An Empirical Analysis of the Trade and Budget Effects”, mimeo, Hamburg Institute of International Economics.

Coe, D.E., E. Helpman and A. Hoffmaister (1997) 'North-South R\&D Spillovers', Economic Journal, January.

Collier, P., Greenaway, D., and Gunning J. W. (1997), 'Evaluating Trade Liberalization: A Methodological Framework'. In Oyejide, A., Elbadawi, I., and Collier, P. (eds.), Regional Integration and Trade Liberalization in Sub-Saharan Africa. Volume 1: Framework, Issues and Methodological Perspectives. London: Macmillan Press Ltd, pp. 306-52.

de Mello, L. (1997), 'Foreign Investment in Developing Countries and Growth: A Selective Survey', Journal of Development Studies, October.

Devarajan, S., W. Easterly and H. Pack (2001), 'Is Investment in Africa Too High or Too Low? Macro- and Micro Evidence', Journal of African Economies, Volume 10, AERC Supplement 2,pp. 81-108.

Easterly, W. (1989). "Policy Distortions, Size of Government, and Growth,” NBER Working Paper 3214. National Bureau of Economic Research, Cambridge, Massachusetts

Easterly, W. (1993) “How Much Do Distortions Affect Growth?” Journal of Monetary Economics. 32(3). Pages 187212.

Feder, G. (1982), “On Exports and Economic Growth”. Journal of Development Economics, 12.

ILO (2000), "Supply Side Constraints that Hamper African Enterprises from Taking Advantages of Emerging Export Market Opportunities. Working Paper PMD, 5.

Iwayemi, A., A. Aminu, and A. Adenikinju (2005), Economic Impact on Nigeria of the Proposed Economic Partnership Agreement with the European: A General Equilibrium Evaluation. A paper presented at the Departmental Seminar, Department of Economics, University of Ibadan, Ibadan.

Karingi, S. R. Lamg, N Oulmane, R. Perez, M. Sadni and H . B. Hammouda (2005), Economic and Welfare Impacts of the EU-Africa Economic Partnership Agreement, United Nations Economic Commission for Africa, Addis Ababa

Levine, R. and D. Renelt (1992), "A Sensitivity Analysis of Cross-Country Growth Regressions", American Economic Review, 82(4), pp. 942-963.

NISER (2003 \& 2004), NISER Survey of Business Conditions, Experience and Expectations in the Manufacturing Sector. NISER Annual Monitoring Research Programme (NARMP), Ibadan: Nigerian Institute of social and Economic Research.

Ogunkola E.O. and A. S. Bankole, 2005. 'Effective Integration of Nigeria in the Multilateral Trading System through Export Promotion' In E.O Ogunkola and A. S. Bankole (eds.), Nigeria's Imperatives in a New World Trade 
Order, Trade Policy Research and Training Programme Department of Economics, University of Ibadan and AERC, Nairobi.

Ogunkola E.O., 2005. 'Agriculture in the Doha Development Round' In E.O Ogunkola and A. S. Bankole (eds.), Nigeria's Imperatives in a New World Trade Order, Trade Policy Research and Training Programme Department of Economics, University of Ibadan and AERC, Nairobi.

Ogunkola, E. O. (2002), “Training, Technology and Productivity of Nigerian Manufacturing Firms”, AERC Special Paper 32, African Economic Research Consortium, Nairobi.

Ogunkola, E. O. (2005), “Integrating West African Agriculture into the Global Trading System: Issues in Regional and Multilateral Trade Negotiations", Paper Presented at the Workshop on "The Trade Negotiations and Development for West Africa: EPA and the WTO” Organised the Economic Community of West African States ECOWAS) and the International Lawyers and Economists Against Poverty (ILEAP). 17-18 October. Cotonou, Benin.

Ogunkola, E. O. and T. A. Jerome (2005) “Foreign Direct Investment in Nigeria: Magnitude, Direction and Prospects”. Final Report Submitted to the African Research Economic Research Consortium, Nairobi, Kenya. March 2005.

Ogunkola, E. O. and T.A Oyejide (2001), “Market Access For Nigeria’s Exports in the European Union: An Assessment of the Impact of the Lome Convention and the Uruguay Round. Nigerian Journal of Economic and Social Studies, 43 (1).

Ogunkola, E.O (2003), Agriculture and the WTO: Economic Interests and Options for Nigeria, in Merlinda, D.I., J. Nash and D. Njinkeu (ed.), Liberalising Agricultural Trade: Issues and Options for Sub-Saharan Africa in the WTO, Published for The World Bank, Macmillan Nigeria Ltd.

Ogunkola, E.O, and A.S. Bankole (2005), "Effective Integration of Nigeria into Multilateral Trading System through Export Promotion “, in Ogunkola, E.O and A.S. Bankole (ed.), Nigeria's Imperative in the New World Trade Order, Trade Policy Research and Training Programme Department of Economics, University of Ibadan and AERC, Nairobi.

Oyejide, T. A. and E. O. Ogunkola (forthcoming) Trade, Investment and Growth in Africa: Patterns, Trends and Puzzles, The Nigerian Journal of Economics and Social Studies

Oyejide, T. A., E. O. Ogunkola and A.S. Bankole (2004), Building Coherence of Objectives, Strategies and. Modalities in the Negotiation of Bilateral, Regional and Multilateral Trade Agreements Involving SubSaharan Africa. A Draft Report Submitted to the United Nations Development Programmes (UNDP),

Oyejide, T.A (2003). Trade Reform for Economic Growth and Poverty Reduction”, Development Outreach, 5(2), July.

Rodriguez, F., and Rodrik, D. (1999), “Trade Policy and Economic Growth: A Skeptic's Guide to the Cross-National Evidence”. NBER Working Paper No. 7081.

Soludo, C. C., O.G. Oji and C. Agu (2003), Potential Impacts of Extension of UEMOA Tariffs to all ECOWASMember States: A Case Study of Impacts of Revenue and Trade balance in Nigeria, Africa Institute of Applied Economics, Enugu, Nigeria.

Srinivasan, T.N., and Bhagwati, J. N. (1999), “Outward-Orientation and Development: Are Revisionists Right?” Mimeo, Yale University.

Thirlwall, A.P. (2003), Growth and Development with Special Reference to Developing Economies, Palgrave Macmillan,Seventh Edition.

Wacziarg, R., 2001, “Measuring the Dynamic Gains from Trade”, The World Bank Economic Review v15, n3, pp. 393429.

WTO (2005), Trade Policy Review, Nigeria, Geneva 